\title{
Female Representations in Byzantine Art of Kosova
}

\author{
Vlora Kosumi Ismaili \\ Department of Fine Art, University of Pristina, Pristina, Kosova \\ Email address: \\ vlora-kosumi@hotmail.com

\section{To cite this article:} \\ Vlora Kosumi Ismaili. Female Representations in Byzantine Art of Kosova. American Journal of Art and Design. \\ Vol. 4, No. 4, 2019, pp. 41-47. doi: 10.11648/j.ajad.20190404.11
}

Received: August 28, 2019; Accepted: October 7, 2019; Published: October 29, 2019

\begin{abstract}
The article addresses the issue of female appearance in the fresco painting from the Byzantine era on the territory of Kosova and aims at disclosure of the methodological approach towards construction of appropriate means for depiction of feminine attributes such are: facial expression, corporal energy, fashion, charm, elegance, grace and physical attractiveness. In that regard, the iconographic configuration of female representation in several churches from the $14^{\text {th }}$ century have been analyzed Shën Premte - Virgin Ljeviška in Prizren, Patrikana e Pejës -Patriarchate of Peja, the Church of the Annunciation in Graçanicë and the Deçan monastery where we encounter a great number of depicted female characters belonging to different categories (female saints - martyrs, female commissioners, images of Virgin Mary etc.) The main aim of the paper is to disclose the manners in which the characters were visualized according to their role in religious history, i.e. describe the iconographic methods applied to each category in order to discover the principles of aestheticism particularly designed for expression of femininity. In that regard, the spiritual tenderness of the images of Virgin Mary, the elegant sophistication of aristocratic female martyrs, the modest and calm beauty of the represented nuns, as well as the dignified portraits of the historic personalities represented as lady commissioners point to different means of iconographic and stylistic expression that were created to live different types of emotional impression by the beholders of the frescoes.
\end{abstract}

Keywords: Female Saints, Women Representation, Byzantine Art, Medieval Churches, Feminine Aesthetics

\section{Introduction}

The treasury of Byzantine art is enormous by the number of art works produced, outstanding by the qualities of their expression and quite elusive when the iconographic character of the depicted themes is in question. However, if one looks at the catalogue of saintly figures visualized across the walls of the Byzantine churches, the first thing that comes to mind is that female characters are not in balance with the male ones, at least by the number and/or frequency of their representations. Although women have been presented in art with many distinctive roles almost its entire history of development [1], they have never required the prominent place occupied by their male "colleagues" (heroes, historical personage, statesmen, tragedy figures etc.). This is even more so in the history of Byzantine art where female characters were usually represented as secondary figures accompanying their male partners or serving as visual aspects of religious iconography, thus testifying to the validity of Biblical and Gospel stories.
However, as some of the Byzantine scholars have clearly shown [2], female images in Byzantine artistic production were the only ones adorned with pure beauty among their numerous manly companions. This implies that the function of the women figures in Byzantine artistic practice was, by all means, dedicated to aesthetic purposes; however, their roles within the fresco arrangements served other intentions, as well [3]. Classifying the female images according to their religious status within the iconographic constellation of their representations, the scholars have established an appropriate typology of the women depicted as individual figures in the frames of representative fresco arrangement created in Byzantium. On a general level, one can assume that the role and status of women in Byzantine art was related to the genus theory of women in the medieval society [4]. On the more sophisticated aesthetic level, women had a particular role in the perception of saintly beauty [5] as a principle of religious practice of the congregation belonging to different social classes and, by all means, to all walks of life. Starting from these notions, we will try to establish the role of women representations in the Byzantine works of art located in the 
territory of Kosova, as a region of a great significance for the development of medieval creativity of the entire Balkan region.

\section{Representations of Virgin Mary}

\subsection{Images of Virgin Mary in Biblical Scenes}

When dealing with female characters and their depictions in Byzantine art, the first individual that comes to mind is the Holy Mother of God, represented without an exception in all fresco ensembles of the medieval era [6]. Positioned in the apsidal conch as the symbol of the earthly Church or located on the wall surfaces and/or pillars under the dome in one of her characteristic iconographic types, the image of the Virgin has always been carefully created due to religious, as well as aesthetic premises. In that regard, the Kosova monuments encompass a great gallery of Virgin Mary's representations, done in different manners and in a palette of distinctive patterns. Among the images of the Virgin that have attracted the attention of scholars and visitors, one has to mention the figure depicted within the composition showing the Ascension in the church of Saint Apostles in Peja from around 1260 [7]. Painted with a great precision, almost icon like, this image of Virgin Mary testifies to the slowly and meticulously applied procedure of drawing, as well as modeling, thus the facial oval appears very vivid, while the figure is monumental, sturdy and highly presentable. Configured with dark hues of warm ecru and highlighted with deep shades of lively brownish valeurs, the face of Virgin Mary looks as if she is going to come down from the heavens and mingle with the congregation in any given moment. Some of the scholars may find this representation of the Holy Mother of God as peasant-like in its painterly spontaneity being so tall and to manly for a woman [8]; however, this depiction of Virgin Mary which dominates the scene of Christ's ascension in the sanctuary of the Peja temple is a unique example of the methodic approach for creation of a female individual liberated from any trace of mysticism and intended to look alike the religious followers that came to the church to behold the frescoes.

\subsection{Individual Images of Virgin Mary}

Much more sophisticated in the painterly manner is the figure of the Holy Mother of God depicted in the apse of the south parekklesion in Graçanicë (ca. 1320) [9], which, although represented in a similar pose, radiates with elegance and graceful gestures. The thin and slender figure, the elongated bodily shape, the slightly accentuated step of the left foot, as well as the long fingers of the hands are highly noticeable features of a female appearance that is presentable, admirable and aesthetically attractive. In the same line, the face of the Virgin is painted in golden beige color, with accents of auburn hues that give the facial expression a noble character and warm spiritual depth. Somewhere in between the two mentioned representations (in Peja and Gracanicë) stands the depiction of the Holy Mother of God on the eastern wall of the exonarthexof the church of Virgin Ljeviška in Prizren (ca. 1310) [10], in which both criteria for dominant energy and delicate expression can be found together. Monumental in the forms yet depicted as a tender and caring mother holding the infant Jesus with her elongated fingers, Virgin Mary in this picture epitomizes a female represented with serenity and grace, yet not lacking any dynamics that unites her with her newborn baby.

\subsection{Images of Virgin Mary and Christ}

However, the most remarkable depiction of Virgin Mary in the Byzantine art of Kosova is the one represented in the sanctuary of the Deçan monastery bearing the epithet "Milostiva" (mid-14 ${ }^{\text {th }}$ century) [11]. Embracing the infant son, she touches his cheek gently as a rose petal falling of the flower, but firmly holding baby's leg for his safety; tenderly looking at the beholders with a silent psychological "gaze", she looks over the child carefully and watches over his undisturbed well-being. Her face is bright and round, highlighted with mild accents of gray and golden ecru, while the saturated color of her garment creates a contrast to the light valeurs of her facial creation. Slightly turned to the left in the direction of the little Jesus, she bends her head for twofold reasons: to give attention to the newborn Savior and to "strike a pose" of femininity and grace, as well. The only comparative example to be linked to this representation is the one depicting Virgin Mary in the illustration of oikos XI of the Akathistos hymn in the same church [12], in which the "flirty" Mother of God holds the baby with both hands and stands tall and elegant in a frontal position. Pretentiously subtle and refined, she symbolizes feminine grace and energy, tender beauty and model-like elegance.

\section{Representations of Female Martyrs}

\subsection{Images of Aristocratic Female Martyrs}

Another interesting example in regard to the women representations in Byzantine mural painting is the depiction of the lady martyrs that are usually located on the side walls of the naos, as well in the narthex of the churches. Depending on the patronage and the function of the temple in which they were pictured, the lady martyrs gained appropriate positions within the fresco arrangement of the edifice as individuals or in distinctively defined groups. In that regard, the group of female saints represented on the pillars of the naos in the Ljeviška church [13] stands out with the delicate manner in which they have been represented. Since the attribution of these frescoes has still being undetermined, we are not sure whether they can be ascribed to the master Michael Astrapas, the signature of whom has been found in the west portion of the temple [14]. However, the sophisticated treatment of their facial features and particularly of their figures and clothing leaves no chance of a doubt. Namely, tall and slender, elegant and graceful, they stand frontally with their hands positioned in a gesture of a silent prayer. Dressed glamorously in silk dresses and velvet capes, ornamented with precious jewelry 
and embellished with luxurious tiaras, Saint Irene, Saint Kiriaki and Saint Barbara by all means epitomize the beauty of female representatives of the church institution. The luxurious materials of the attires woven with silk threads and the golden earrings ornamented with precious stones, in this case, are only a supplement to the irresistibly depicted female characters grouped in a constellation of "visual esthetics" in the west portion of the edifice.

In that sense, these saintly figures represented in the Ljeviška (Shën Premte) church can be seen as a picture of lady aristocrats whose images radiate with feminine graciousness and tender physical attractiveness. Thin and elegant, beautiful and charming, they comprise all characteristics of desirable outlook in terms of facial, figural and fashionable appearance. Fair in the exhibition of the images, elastic in the presentation of the bodies and modern in the display of the couture, the pictures of the female saints belonging to the category of nobility in Ljeviška - Shën Premte church radiate with facial charisma, figural energy and accentuated social potency. The attractive silhouettes of their figures and the noble "demeanor" of the poses, the mild modellation of the images, the gracious contours of the bodies and the luxuriously designed costumes, altogether with the elegant motion as well as gentle facial expression, result in the most desirable form of a human beauty in the esthetic horizon of byzantine painting found in the territory of Kosova. Glowing ochre for the tan, silky pink nuances for the chicks, pale rose tones for the lips and a great palette of colours for the glamorous clothing, are the features of the chromatic diapason for the depiction of the sophisticated beauties of the Holy Virgin Ljeviška - Shën Premte temple. The refined complexion of the aristocratic face of Saint Barbara [15], the subtle motion of her hands that glide down the glamorous dress, the elongated neck and the delicate "make up" traces visible on her complexion point to the most beautiful female figure in the entire fresco ensemble of the Ljeviška - Shën Premte church. Complemented with an astonishingly expensive clothing made of crimson red velvet and massive golden earrings, this figure of Saint Barbara can compete with the highest attainments of painterly beauty in the artistic production of the Byzantine world.

\subsection{Images of Spiritual Female Martyrs}

In contrast to these extraordinary feminine appearances of the women saints in Ljeviška - Shën Premte, in Graçanicë we have completely different story. In this church, we find another type of female beauty - the one dedicated to the religious notion of modesty. Dressed as nuns and positioned in a figural representation of serenity and devotion, these women figures embody the humble and god-fearing female gender, represented in subservient stances and modest monastic clothing [16]. Due to their status of convent inhabitants and, accordingly, of persons renounced of all laymen benefits, the holy nuns are depicted with a minimum of elements in regard to their physical appearance and social features [17]. In that sense, the anatomy of the figures of Saint Pelagia of Antioch and her name sake of Jerusalem [18] is purposely hidden beneath the loose robes, while their gestures are reduced to the obedient motion of a prayer. The calmness of the serene faces and the graceful movements of the elongated fingers are the only features that display feminine attitudes, which can be determined as physically attractive and visually likable. Liberated from any emotional residue of their earthly life that could distort the peaceful architecture of the facial tranquility, the holy nuns reflect only the inner beauty of their souls, manifested through the calm silhouettes of their facial, as well as corporeal appearance.

Dressed in dark garments and represented in static posture, i.e. a pose with minimum elements of corporal motion is the figure of Queen Jelena, depicted next to her son, both pictured as monastic characters on the eastern wall of the narthex of Graçanicë [19]. The darkish complexion permeated with deep, brownish shades, the minimum modeling of the figure, the modest dress with no ornamentation whatsoever, the static posture, as well as the serious facial expression of Saint Jelena - the nun emanate rigidity in the painterly procedure of its creation, testifying to the methodological approach significant for the depiction of monastic female figures. The same approach is visible in the representation of Saint Mary of Egypt situated on the northern wall of the parekklesion dedicated to Saint Demetrios in Deçan [20]. This female figure known for her penitent destiny is the most ascetic character among the woman saints in Byzantium; therefore, she is represented as an old, exhausted individual with scars on her body, limp skin and withered extremities that can be seen beneath her modest, dark and lose clothing. The short, gray hair, the dark tan, the tired complexion and the bony corporal appearance of Saint Mary of Egypt epitomize devotion and commitment; yet the bare legs and the elongated extremities bear the visual memory of her - once a beautiful woman and an attractive female figure. Thus, the beauty of the female saints in Byzantium, depicted in the fresco arrangements of medieval churches, have multiple horizons of perception - as an aristocratic attraction, as a modest yet tentative appeal, even as a rigid and ascetic affinity.

\section{Representations of Female Donors}

\subsection{Images of Queen Jelena}

The most interesting category of female representations is, by all means, the one encompassing the donor portraits of women who belonged to the highest social circles of medieval history [21]. The methodology of design in the structure of donors' arrangements, once again, reveals the domination of male characters [22]; however, there are commissioners' compositions in which female representations are visually far more imposingly attractive than their male counter partners. One of the examples that prove the above stated is the picture of Queen Jelena on the western wall of the southern chapel in Deçan [23]. Tall and dignified, elegant and graceful, Jelena stands in a frontal 
pose, petting her son with a gentle motion of her right hand thus expressing a warm motherly love. Dressed in a long, luxurious and tailor made dress that exposes her immaculate figure and raising her left hand in a gesture of a courtly salutation, she is represented as a remarkable woman, marked by lavish beauty and noble personal character. With pale composure, cherry red lips, large brown eyes and elongated neck hidden beneath the neck dress and massive golden earrings, she stands proud of her ancestry and offspring as one of the most beautiful women of the medieval Balkans.

\subsection{Images of Empress Jelena}

Another example of a dignified position in the representation of a female character, is the donor scene depicted on the northern wall of the narthex in Deçan which we see mother (women) in a different visual and social context [24]. Namely, pictured a few years later than the mentioned one, the portrait of Jelena in the narthex represents her as an Empress, i.e. the highest government authority a woman can gain. Therefore, Jelena in the narthex compared to Jelena from the southern chapel is depicted with a much more austere facial expression emanating strength, potency and power rather that tenderness and grace. Her outfit is also more restrained in terms of lavish ornamentation and displays a taste for simplicity rather than resplendence. Represented in smaller dimensions in regard to her husband, she does not look as a submissive individual in the picture; on the contrary, she looks as more subtle and more unpretentious unit of the imperial couple, which was her actual role in terms of political history. Still, her elegant posture, handmade garment, as well as graceful motion towards the central position of her husband, speak in favor of the "social elegance" of Jelena as one of her most distinctive features as a woman.

\subsection{Images of Royal Female Characters}

Although Jelena was, most probably, the most attractive woman represented in the medieval frescoes of Kosova, two other female characters cannot be excluded when one talks about femininity in fresco painting. Namely, if we look at the Nemanja Family Tree in Graçanicë, located on the eastern wall of the narthex [25], we will see two very distinctive woman figures in the third and fourth row of the composition. Those are King Milutin's sister Prnjaça and his daughter - Carica [26]. While Prnjaça wears green dress ornamented with golden embroidery, King Milutin's daughter Carica is dressed in purple garments, which is but a visual explication of her royalty, i.e. succession in the blood line of the governor of the state. Apart from the political messages visualized through pattern and colors, the two ladies emanate elegance and grace in their postures, as well as in their bodily features. However, the primate of beauty is, once again, given to the king's daughter rather to his sister in terms of height, slenderness and facial expression. Carica is taller than Prnjaça, she is thinner than her aunt, features that can be, no doubt, ascribed to the age difference; yet, the lavishly decorated garments of Carica and her accentuated facial sophistication speaks of nothing else but the notion of King's favorite child pictured as a model like figure among the representatives of his large family.

\subsection{Images of Princess Simonida}

However, if one should point out the most representative female figure in the entire history of Byzantine art on the territory of Kosova, it would, no doubt, be the picture of Queen Simonida depicted within the commissioners' scene on the pillars situated between the naos and the narthex in Graçanicë church [27]. Placed on the architectural carriers of the temple, the king and his wife are represented as the two powerful columns of the state - the old ruler and his young bride brought from the Byzantine Empire to fortify the alliance between the two political powers in the Balkans. Aside from the political connotation of the two portraits, the one depicting Queen Simonida has pure esthetic features, as well. Namely, she is represented facing forward, with pale complexion, lavish crown and a golden hallo around her head. She holds a scepter in her right hand, while the left one is raised in a gentle motion of a prayer. Her face is oval like, with a long and narrow nose, small mouth and arched eyebrows. As a head dress, she is wearing an open crown, decorated with rubies, emeralds and pearls. Below the crown, there is a kerchief covering her hair and falling down to her shoulders. In regard to the garments, Simonida is dressed in granatza [28] - a long, crimson red dress and a cloak. The dress is ornamented with embroidery, while the cloak is decorated with golden stripes and attached precious stones. She wears massive golden earrings decorated with pearls.

In terms of the painterly approach and methodology of creation of this portrait, her face is represented idealized, with noble character, zero facial expression and light pinkish accents to her cheeks. The figure is tall and slender, but without any hints of anatomy beneath the luxurious garment. In comparison to the portrait encompassed by the commissioners' scene in the narthex of the church dedicated to Saint George in Staro Nagoričino [29], depicted a couple of year earlier, Simonida from Graçanicë is thinner, paler and more elegant. Although in both representations she wears similar garments and almost the same jewelry, the queen in Graçanicë picture looks more lavishing due to the tailor made costume ornamented with tiny details in comparison to her dress in Staro Nagoričino created more traditionally. Despite the destruction of the Staro Nagoričino scene which is at present day hardly visible, one can notice the slight difference in creation of the queen's figure: in Staro Nagoričino, Simonida's picture is highly conventional, while in Graçanicë is embellished with a hint of greater femininity in the exposition of her slender and elegantly positioned figure. All in all, between the two portraits of 
Queen Simonida preserved in the cultural heritage of the Byzantine era (in Staro Nagoričino and Graçanicë), the one in Graçanicë radiates with the depressed feminine energy of the young Byzantine princess who has been brought to consol the aged King Milutin.

\section{Conclusion}

As our examples of represented women figures have clearly shown, female characters gained very distinctive place among the individuals portrayed in the Byzantine fresco painting on the territory of Kosova. Attractive as representatives of the aesthetically superior gender, the female figures in the Holy Virgin church Ljeviška (Shën Premte) in Prizren, church of the Annunciation in Gracanicë, Deçan monastery and the Patriarchate in Peja were glowing with sparkles of attraction in the eyes of the beholder who entered the temples in pursuit of religious assistance. Radiating with charm and dignity, shining with elegance and gracefulness and impressing with courtesy and manners, the female saints, as well as the historic female characters have not only beautified the vision of the congregation, but have also given their most presentable appearance to the perception of aesthetic horizon of the painterly production in Kosova. The ravishing purity of the images of Virgin Mary, the tender and graceful modesty of the nuns, the fashionable and extravagant styling of the lady aristocrats, as well as the radiating glow of Empress Jelena and Queen Simonida in the painting of the above mentioned monuments, are the main features of the catalogue of pure beauty, feminine energy and aesthetic charm created in the frescoes of medieval Kosova.

\section{Appendix}

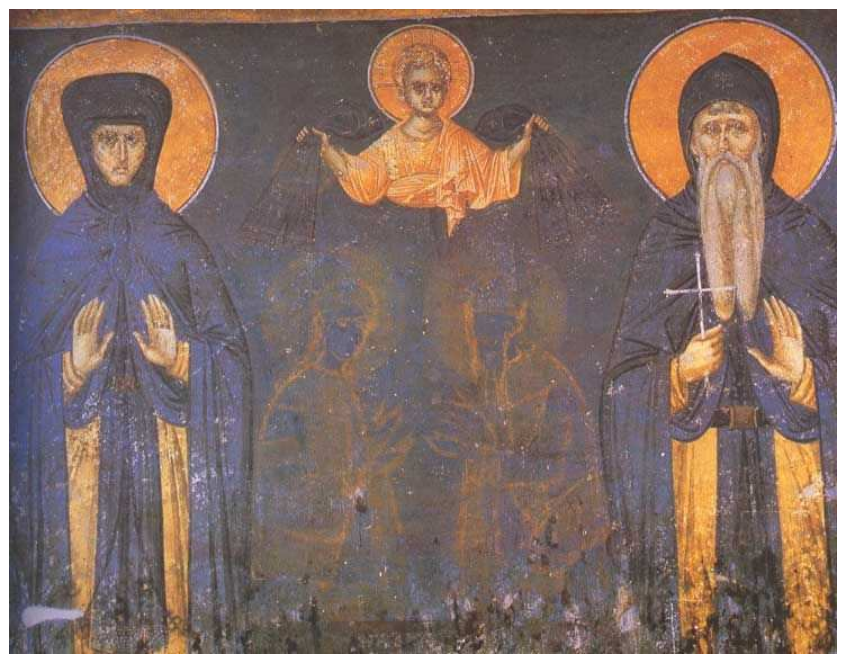

Figure 1. Graçanicë, Queen Jelena as a nun with son Milutin.

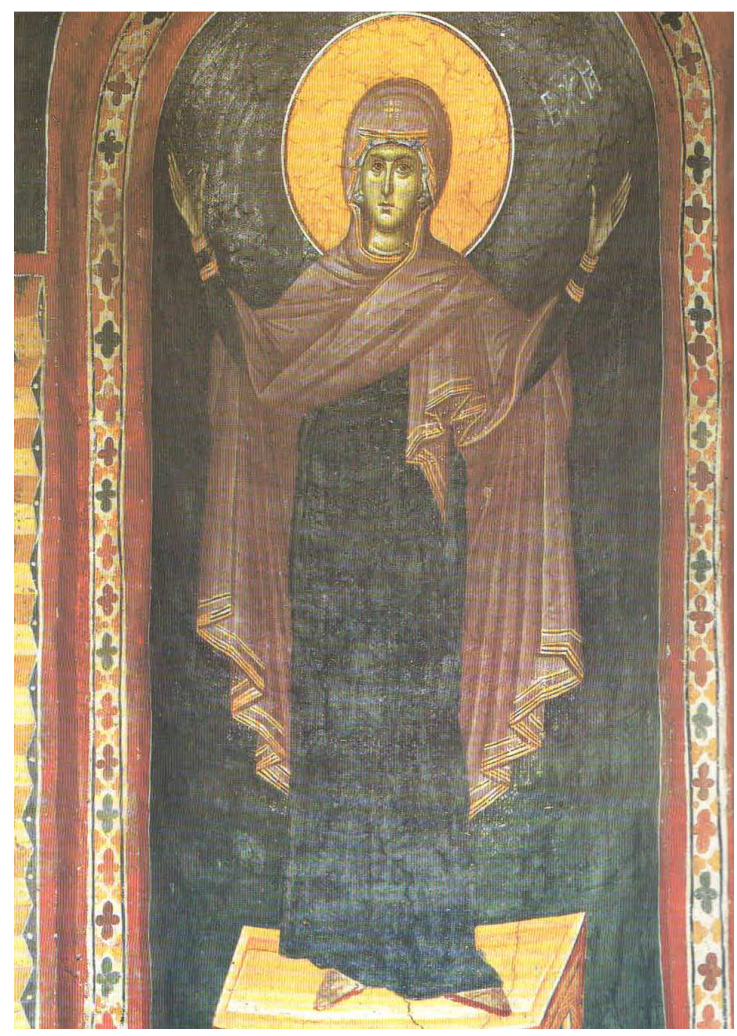

Figure 2. Graçanicë, Virgin Mary from the south parakklesion.

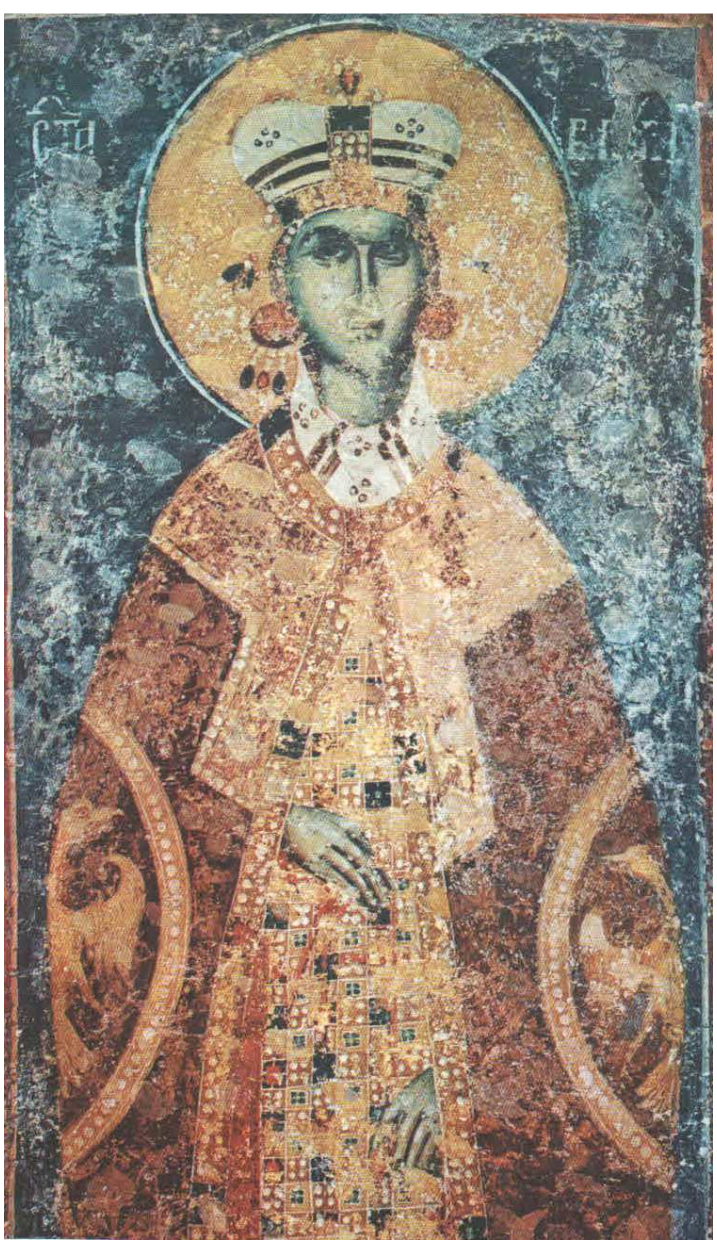

Figure 3. Holy Virgin Ljeviška in Prizren, Saint Barbara 


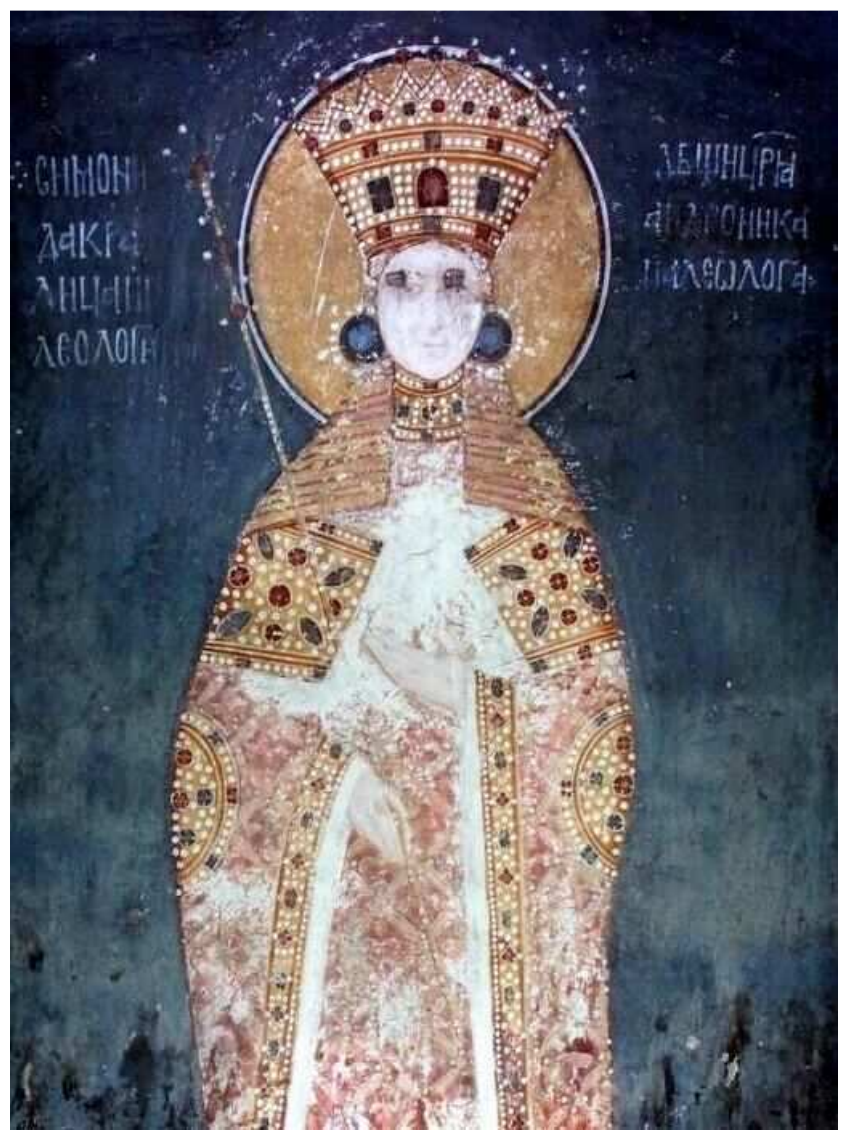

Figure 4. Queen Simonida from the commissioners'scene in Graçanicë.

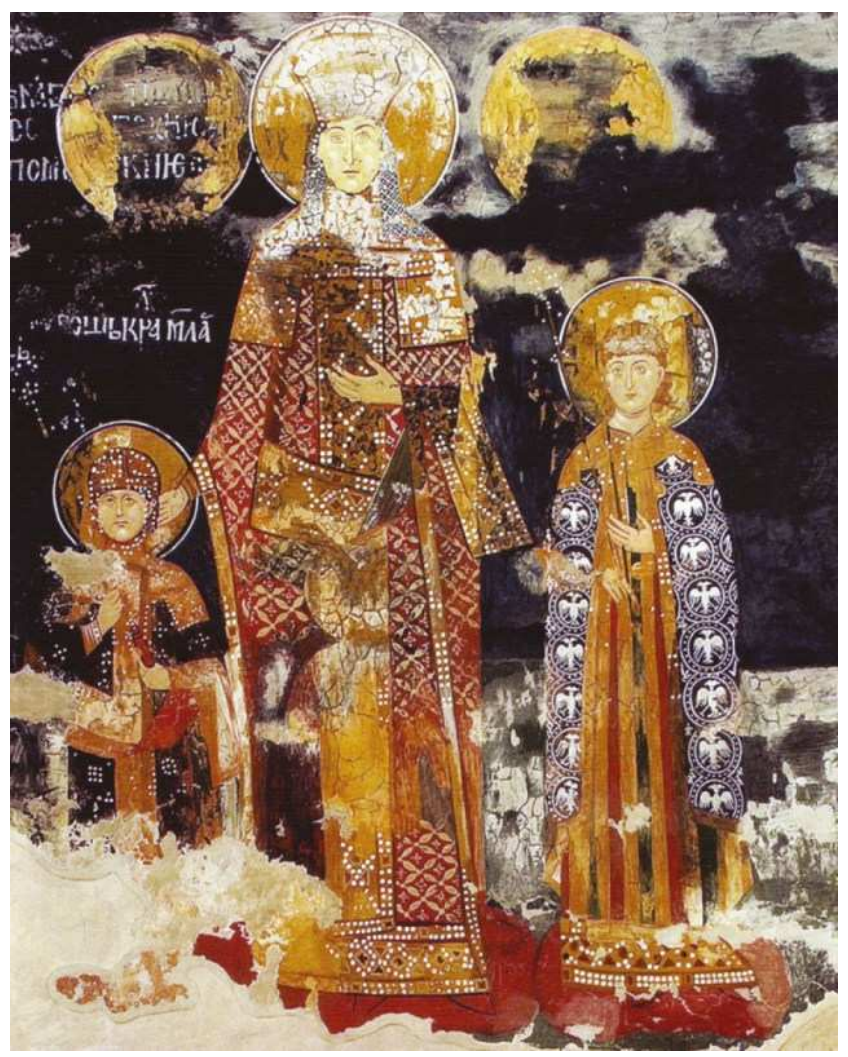

Figure 5. Deçan, Empress Jelena with her son Urosh and Simeon Sinisha.

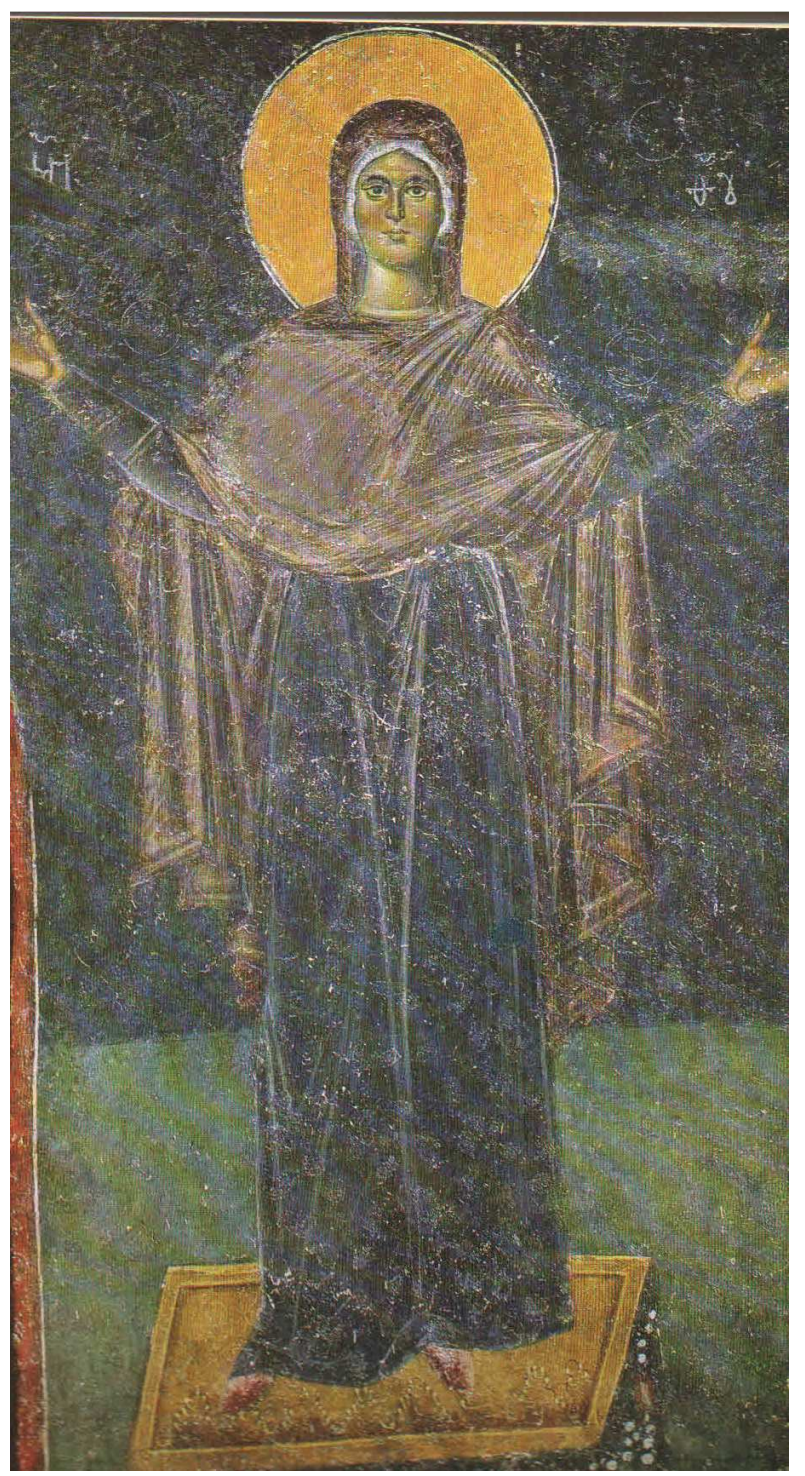

Figure 6. The Patriarchate of Peja, Holy Mother of God from the scene of Ascension.

\section{References}

[1] E. Dimitrova, "AnimaePulchrae: Depiction of Saintly Images in Byzantine Mural Painting", in Perception of Beauty (ed. M. P. Levine), Rijeka 2017, pp. 34-35.

[2] Particularly when historic characters are in question, cf. M. Cartwright, "Women in Byzantine Empire", in Ancient History Encyclopedia, Oxford 2018.

[3] E. Dimitrova, "Colourful Sparkles of Imaginary Vistas: Saintly Beauty in the Eyes of the Beholder", in Zograf 37, Belgrade 2013, pp. 83-84.

[4] E. Pilts, "Byzantine women's visibility in the arts", in: Proceedings of the $21^{\text {st }}$ International Congress of Byzantine Studies, vol. III, London 2006, p. 101-102.

[5] E. Dimitrova, "Amazing Vistas: Depiction of Male/Female Beauty in Byzantine Fresco Painting", in Proceedings of the $22^{\text {nd }}$ International Congress of Byzantine Studies, vol. III, Sofia 2011, p. 265. 
[6] J. Lafontaine-Dosogne, "Iconography of Mary, Blessed Virgin", in New Catholic Encyclopedia, Farmington Hills 2003, pp. 77-82.

[7] V. J. Đurić, Vizantijskefreske u Jugoslaviji, Beograd 1974, p. p. 37, Pl. XXIII.

[8] V. J. Đuric, Vizantijskefreske u Jugoslaviji, Beograd 1974, p. 38.

[9] B. Todic, Serbian Painting in the Age of King Milutin, Belgrade 1998, T. XXXIII.

[10] D. Paniċ, G. Babic̈, BogorodicaLjeviška, Beograd 1988, p. 67.

[11] B. V. Popovic, "Program živopisa u oltarskomprostoru", in ZidnoslikarstvomanastiraDečana. Građa i studije, Beograd 1995, Figure 1a.

[12] G. Babic̀, "Bogorodičin Akatist", in Zidno slikarstvo manastiraDečana. Građa i studije, Beograd 1995, Figure 12.

[13] D. Panić, G. Babiċ, BogorodicaLjeviška, pp. 57-58.

[14] P. Miljković-Pepek, Deloto na zografiteMihajlo i Eutihie, Skopje 1967, pp. 228-230.

[15] D. Panic̀, G. Babic, Bogorodica Ljeviška, T. XXVII.

[16] H. Maguire, The Icons of Their Bodies. Saints and Their Images in Byzantium, Princeton 1996, p. 28.

[17] E. Dimitrova, "Colourful Sparkles of Imaginary Vistas: Saintly Beauty in the Eyes of the Beholder", p. 83.

[18] B. Todic, Gracianica. Slikarstvo, Beograd - Priština 1988, Figure 90 .

[19] B. Todić, Graćanica. Slikarstvo, Beograd - Priština 1988, p. 130-130, T. XXVII.
[20] M. Marković, "Pojedinačne figure svetitelja u naosu i paraklisima", in ZidnoslikarstvomanastiraDečana. Građa i studije, Beograd 1995, pp. 250-251.

[21] On the depiction of donor characters, male and female, see: R. Franses, Donor Portraits in Byzantine Art, Cambridge 2018.

[22] E. Dimitrova, "The Portal to Heaven. Reaching the Gates of Immortality", in Niš \& Byzantium Symposium. Collection of scientific works V, Niš 2007, pp. 367-380.

[23] D. Vojvodic, "Portreti vladara, crkvenih dostojanstvenika i plemica u naosu i priprati”, in Zidno slikarstvo manastiraDečana. Građa i studije, Beograd 1995, Figure 15.

[24] D. Vojvodic, "Portreti vladara, crkvenih dostojanstvenika i plemica u naosu i priprati", in Zidno slikarstvo manastiraDečana. Građa i studije, Beograd 1995, Figure 20.

[25] B. Todic̀, Gračanica, Slikarstvo, p. 130.

[26] M. Markovic, "Under the First Rulers of the Nemanjic Dynasty (from 1168 to the Death of King Milutin) ", inArtistic Heritage of Kosova and Metohija, Belgrade 2017, Figure 204.

[27] B. Todic, Serbian Painting in the Age of King Milutin, T. XXVII.

[28] D. Pavlovic, "Queen Simonis", in Serbian Artistic Heritage in Kosova and Metohija, Belgrade 2017, pp. 218-219.

[29] B. Todič, StaroNagoričino, Beograd 1993, pp. 118-119; E. Dimitrova, "The Church of St. George at StaroNagoričino", in Seven Medieval Churches in the Republic of Macedonia, 2014, Figure 11; E. Dimtrova, G. Velkov, Sedum srednovekovnicrkvivoRepublikaMakedonija, Skopje 2015, p 92. 